\title{
Inter-Organizational Collaboration on Projects Supporting Sustainable Development Goals: The Company Perspective
}

\author{
Iwona Escher*(i) and Pawel Brzustewicz ${ }^{(\mathbb{D})}$ \\ Department of Organizational Behavior and Marketing, Faculty of Economic Sciences and Management, \\ Nicolaus Copernicus University, 87-100 Torun, Poland; pbrzustewicz@umk.pl \\ * Correspondence: escher@umk.pl
}

Received: 1 June 2020; Accepted: 16 June 2020; Published: 18 June 2020

check for updates

\begin{abstract}
There is a significant research gap in the theory of the nature of relationships between companies and other organizations (including NGOs) when collaborating on projects to support sustainable development goals. In particular, the company perspective has not yet been analyzed in depth. This paper therefore presents these relationships from the company's point of view, and particularly in terms of how company representatives describe the roles of each partner in the collaboration and the outcomes it generates for the company. The empirical research is theoretically grounded in the Activities-Resources-Actors (ARA) model developed by Håkansson and Snehota. The study adopted a qualitative approach and was conducted using semi-structured individual in-depth interviews in 18 companies; the companies represented different industries and were involved in different types of projects related to sustainable development goals. The paper contributes to developing the theory in various ways. It contributes to the understanding of processes related to company involvement in sustainable development. It also contributes to the theory of the essence and substance of inter-organizational relationships, and specifically the ARA framework. Moreover, it explains the specificity of such inter-organizational collaborations and identifies to what extent these relationships vary from other types of inter-organizational collaboration, especially from business-to-business relationships. The paper also contributes to the discussion on the role of personal bonds within such inter-organizational relationships. The practical implications relate to the ways in which the activities and resources of a company and its partner may be combined in projects addressing social and/or environmental problems. Therefore, the paper offers guidance to companies and their potential partners interested in undertaking joint sustainability initiatives.
\end{abstract}

Keywords: inter-organizational collaboration; projects for sustainable development; ARA model

\section{Introduction}

For the past few decades, the environmental and social consequences of human economic activity have been receiving growing attention. Along with this, the concept of sustainable development (SD) has been developing and gaining in importance [1-3]. Within SD, a central role is played by companies, as their activities affect not only the economy but also society and the natural environment [4-6]. It is recognized that without the engagement of companies, SD goals cannot be realized.

Companies can contribute to SD through a wide range of activities [4,7-11]. These include projects supporting the achievement of sustainable development goals. In this article, this term is used interchangeably with "projects for sustainable development" or "projects for SD" or "SD projects", and we use it to refer to all types of planned, organized activities undertaken by a company and its employees to solve particular social and/or environmental problems. To avoid ambiguity, activities relating directly to the economic dimension of SD are excluded from this definition. 
The number of companies involved in such activities is growing, and there is a great variety of projects that they undertake-from one-off actions and projects purely limited to transferring funds or prizes, food, clothing, etc. to meet specific social or environmental goals, up to regular activities actively involving a firm's employees as part of a formal volunteer program within the company [12-16]. Many such projects are realized by companies independently, but a significant number are also undertaken in collaboration with various partners.

Notwithstanding the rich literature on companies' contributions to SD $[4,9,17-19]$ and on companies' collaborations with other types of organizations (chiefly with other enterprises to achieve business goals [20-24]), there are fewer publications dealing with the issue of inter-organizational collaboration in relation to company engagement in projects supporting SD goals [25]. Of the research areas within this topic, the one most studied and described in the literature to date has been company-NGO collaboration on such projects [26-33]. However, practice shows that partners in such collaborations are more diverse, and leads us to expect that: (1) the ways of carrying out such collaborations may be more varied than in the case of company-NGO relationships, and that (2) the outcomes it generates for companies may be more varied. Additionally, the specificity of such collaborations leads us to expect that we may be able to identify some aspects of such collaborative initiatives that they share regardless of the type of collaborative partner, and that at the same time it may distinguish them from other types of inter-organizational relationships (and especially from business-to-business (B2B) partnerships).

In search of support for such assumptions, we analyze in detail selected cases of collaboration undertaken between companies and other organizations in the form of the projects to solve specific social and/or environmental problems. More precisely, we intend to respond to two central questions: (1) what is the nature of such collaboration? and (2) what kind of outcomes does it generate for companies?

The methodological foundation for our analysis was the ARA (Activities-Resources-Actors) model developed by Håkansson and Snehota [20], as one of the various frameworks for studying and explaining the nature of inter-organizational collaboration [23,26,27,34-36]. It was selected for three main reasons. Firstly, the ARA model is a very well-known model in the literature, and it is frequently referenced by a wide community of researchers to analyze dyadic relationships and networks in industrial markets $[37,38]$. However, and this is the second reason we chose it, the model is not used with the same frequency with other types of inter-organizational relationship. Thus, by using the main constructs (elements) of the model to describe the nature of the relationship between companies and other organizations on SD projects we could demonstrate its usefulness outside the industrial context. By so doing, we also could enrich the model by applying it in the new context of collaboration that differs from the typical buyer-seller relationship. Given the general nature of the model [20,38], such an application could also be acknowledged as beneficial to its operationalization. In actual fact, the relatively abstract and parsimonious form of the ARA model was the third reason we chose it for our analysis. The generalized nature of the model allowed us to apply it and have insights into the relationship we were interested in, making clear who the actors are and what activities and resources we should take into account when analyzing data.

Our empirical data come from qualitative research conducted in the form of semi-structured individual in-depth interviews (IDIs) in 18 companies operating in Poland, representing different industries, and declaring involvement in different types of projects supporting the achievement of SD goals. Nine of these 18 surveyed companies were selected for more in-depth analysis. They were those companies in which a successful project indicated by respondents had been realized in collaboration with other organizations, and to which questions referring to the ARA model were thus applicable.

We describe the ARA model in more detail in the 'Literature review' section, where we also present basic theoretical considerations regarding different forms of company engagement in SD, including projects supporting SD goals and possible ways of undertaking these projects. In the next part we present the main characteristics of the conducted study. Subsequently, in Section 4, the main results of the study are introduced. Specifically, Section 4.1 presents the main characteristics of the 
projects for SD undertaken in collaboration by the surveyed companies. In Section 4.2, nine selected joint projects are described in depth. Based on the ARA model, the activities and resources contributed to these projects by each partner are presented (Section 4.2.1), as are the roles that actor bonds played in initiating and undertaking these relationships (Section 4.2.2). The empirical part of the article ends with a presentation of the positive and negative effects that the analyzed collaboration brought the companies (Section 4.3). In the final section, we discuss the main results of the study from the perspective of the research questions and the literature. It also presents the limitations of the study and possible future research directions.

\section{Literature Review}

\subsection{Company Involvement in Sustainable Development}

Many environmental and social problems, such as climate change, increasing inequality, poverty, loss of biodiversity, and food insecurity, have long been underestimated by business [39]. However, since the 1960s, societal expectations of business's contribution to resolving these problems have been growing [29]. In addition, companies have found that, faced with increasing global competition, their environmental and social activities are important elements of building social trust, and thus a positive image [4,40-42]. Such activities can also be the source of other long-term benefits for companies, such as financial, relational, operational and organizational gains $[4,43,44]$.

Consequently, even more companies are engaging in sustainable development. Their involvement in SD may take different forms. For example, it can be realized by developing sustainable products and services, implementing sustainable distribution, caring for employees and local communities, introducing codes of ethics, applying social reporting, implementing environmental management systems or engaging with stakeholders along the value chain $[4,9,11,45,46]$. These activities are most often implemented at the company level as part of the concept of corporate social responsibility (CSR). CSR is based on companies' voluntary integration of social and environmental issues both in business operations and in interactions with stakeholders [47]. The growing popularity of CSR shows that issues related to implementing sustainable development are currently of strategic importance to many organizations.

Company engagement in SD may be realized independently, based only on the company's own resources and activities, or in collaboration with other organizations. Considering the multitude of environmental and social problems, and their complexity, inter-organizational partnership in many cases seems to be the most appropriate way to implement SD goals $[5,39,48]$. In actual fact, there is a wide range of partners for companies in such a collaboration, including other companies, chambers of commerce, local authorities, universities, public institutions, and non-governmental organizations (NGOs) [39].

Joint projects supporting SD goals constitute one example of such collaborative SD activities undertaken between companies and other organizations. Even if company-NGO collaboration on such projects is the most common, as well as being the most well studied and described in the literature [26-33], there may be more diverse partners in such collaborations. Regardless of the type of such partners, their collaboration with companies on such joint projects could be considered an example of an inter-organizational relationship.

The subject of inter-organizational relationships has been extensively described in management studies since the 1980s at least. There are a significant number of publications presenting many aspects of such relationships in detail, but most refer to business-to-business collaboration [20-24]. Consequently, there is a wealth of guidance and frameworks for analyzing and understanding how the partners in such B2B partnerships might interact, and what the potential positive and negative outcomes might be for each partner $[23,34,36]$. Notably, the research carried out by the Industrial Marketing and Purchasing Group has made a considerable contribution to this issue, particularly the 
ARA model by Håkansson and Snehota proposed within the industrial network approach developed by that group of scholars [20].

\subsection{The ARA Model}

The ARA model is considered to be a useful basic framework for researchers attempting to operationalize business-to-business relationships and study the interdependencies between a company and its partners [20,37,38]. According to Håkansson and Snehota [20], interactions between three basic elements (Activities-Resources-Actors) related to cooperating participants constitute the three main layers of the substance of B2B relationships. The authors define them precisely as: (i) the activity layer, i.e., activity links that connect, more or less closely, various actions undertaken by relationship partners, (ii) the resource layer, i.e., ties between the resources that each partner in a relationship possesses and controls, and (iii) the actor layer, i.e., actor bonds, which can be understood both as interactions between two companies (collective actors) and as personal ties connecting the employees (individual actors) representing these two interacting partners [20,49,50].

These three layers are closely interrelated, but the way they are combined and their strength and importance in the structure of relationship layers may be different, which determines the great variety of existing B2B relationships [20,49]. Hence, despite the fact that the concept of interaction between activities, resources and the actors seems to represent a heterogeneous pattern in theory, in practice these combinations within and between business partners are not uniform across all of a company's relationships [51]. There is always a unique pattern of interactions between a particular company and each of its counterparts [51]. There are B2B relationships that mainly consist of actor bonds, whereas in other relationships the activity links are strong while actors bonds or resource ties are weak, or relationships exist in which bonds between actors and resource ties have developed but without many activity links [20]. There is also a possibility of developing closer links, ties and bonds in existing relationships over time. And conversely, with time, existing links, ties and bonds may undergo significant disintegration, deterioration, interruption, dissolution or termination as a result of actions undertaken by the parties.

Although the ARA model is frequently used to analyze dyadic B2B relationships, it also takes into account the consequences of going beyond the specific relationship in which the links, ties and bonds arise. As Håkansson and Snehota emphasize [20], the effects of an existing relationship between two companies are not limited to the two companies involved: other parties and relationships (being a part of the network structure) may also be affected. Any change in a relationship can change the development potential of the relationship, can affect the companies involved (their internal features) and can indirectly affect the overall network [20]. A third party to the relationship can be affected by the ways in which the content of a relationship develops; it may take advantage of, or squander its development but it too can affect the relationship [49].

Whilst the ARA model was developed based on research mainly into cooperation between business partners, we consider it to be applicable to the study of the relationships that are the main subject in this article. The model, despite its popularity among many researchers, still has a somewhat general form and has not yet been thoroughly operationalized [52], in particular with regard to inter-organizational collaboration between companies and other organizations in projects supporting SD goals. We therefore consider it interesting to use it to describe in depth the nature of such a collaboration. Focusing on examples of successful joint SD projects, we demonstrate the ways in which they combined the activities and resources of both parties, as well as the role played by actor (interpersonal) bonds in initiating and undertaking such collaborations. We also intend to discover whether the sustainability context of such partnerships is reflected in differences between the resources and activities contributed by each partner, the personal ties connecting their employees, and the outcomes for companies (compared to B2B partnerships). 


\section{Research Methodology}

\subsection{Method}

The engagement of companies in Poland in implementing sustainable development goals, especially in projects in collaboration with other organizations, still has a relatively short tradition. Our preliminary desk research indicated that those companies most experienced in this area are primarily local Polish units of multinational corporations. This fact was reflected in the structure of the research sample that we drew for our empirical study (see Section 3.2). Referring to the two central questions proposed in this article (see Introduction), the following four research questions were defined for the study:

- $\quad$ with respect to the first central question (on the nature of the investigated collaboration):

(1) What activities and what kinds of resources are contributed by each partner when collaborating on joint SD projects?

(2) What is the role of actor (interpersonal) bonds in initiating and undertaking such collaborations?

- $\quad$ with respect to the second central question (on the outcomes generated for companies):

(3) What are the positive effects of this collaboration for companies?

(4) Are there any negative effects of this collaboration for companies?

To answer these questions we conducted qualitative research. The choice of this type of research resulted directly from the aims to be achieved and the current state of knowledge in the subject of the study, which in the Polish context in particular has not yet been thoroughly researched and described. In such a situation, it is recommended to conduct a qualitative study, as this can support researchers in better understanding the general nature of the topic and in generating preliminary insights and ideas rather than making generalizations [53-57]. A quantitative study would require a high level of prior knowledge, which did not exist when this research project was first planned.

Within qualitative methods, we used semi-structured individual in-depth interviews since they are the recommended method when respondents are professional people or the research subject is related to their jobs [58], as was the case in our study (for more on respondents, see Section 3.2).

During IDIs, respondents were asked, among other things, to describe in depth one particular SD project that had been implemented in their company and that they assumed to be the most successful of all projects realized in the three years preceding the interview. (We did not suggest how the respondent should interpret the term 'the most successful', leaving them to their own interpretation.) When the respondent indicated the successful project as a project that had been realized in collaboration, the additional questions from the IDI guide referring to the ARA model were asked during the interview.

The interviews were conducted in May-June 2018. Each IDI took 60-90 min and was recorded and transcribed. In order to minimize research bias during data analysis and interpretation, more researchers were combined and one, generally binding code book was introduced. With the help of such a code book, the transcriptions were independently coded by a minimum of three researchers using MAXQDA software (version 12, developed and distributed by VERBI Software, based in Berlin, Germany) and later their results were shared to reach a consensus.

\subsection{Respondents and Investigated Companies}

The subject of our interest was companies operating in Poland that had declared involvement in different types of projects supporting SD goals. The selection of the companies was purposive, which is a commonly used approach in qualitative research $[55,56]$. In accordance with qualitative research practice, we continued selecting subsequent companies for the sample until theoretical saturation was reached $[55-57,59,60]$. 
In total, we conducted the study in 18 companies meeting the selection criteria (see Table 1). Due to data confidentiality we refer to them as company A, company B, company C, etc. All but three were Polish subsidiaries of international corporations-some were established in Poland by foreign companies, while the others were primarily national companies that had been acquired by international corporations. Nine of these 18 companies were selected for more extensive analysis presented in Section 4.2. They were those companies in which the successful project indicated by the respondents had been realized in collaboration with other organizations, thus making the questions referring to the ARA model applicable to them. These companies are indicated in Table 1 by a $\left.{ }^{*}\right]$ sign beside their code.

Table 1. Characteristics of investigated companies.

\begin{tabular}{|c|c|c|c|c|}
\hline $\begin{array}{l}\text { Company } \\
\text { Code }\end{array}$ & Industry & Area of the Company's Main Activity & $\begin{array}{l}\text { Dominant } \\
\text { Capital }\end{array}$ & $\begin{array}{l}\text { Year Operations } \\
\text { Began in Poland }\end{array}$ \\
\hline$A^{*}$ & Service & Insurance & British & 1992 \\
\hline$B^{*}$ & Service & Bank & French & 2008 \\
\hline $\mathrm{C}$ & Service & Bank & Polish & 2001 \\
\hline $\mathrm{D}$ & Service & Consulting & French & 1996 \\
\hline$E^{*}$ & Production & Building materials & Mexican & 1996 \\
\hline $\mathrm{F}$ & Production & Refrigeration, air conditioning and heating & Danish & 2001 \\
\hline$G^{*}$ & Service & Bank & Dutch & 1996 \\
\hline $\mathrm{H}$ & Service & Sales of construction machinery & Dutch & 2001 \\
\hline $\mathrm{I}$ & Service & Telecommunications & French & 2005 \\
\hline $\mathrm{J}$ & Service & Railway carrier & Polish & 1926 \\
\hline$K^{*}$ & Service & Home-credit and digital consumer finance & British & 1997 \\
\hline $\mathrm{L}^{*}$ & Service & Logistics & Dutch & 1991 \\
\hline$M^{*}$ & Service & Logistics & German & 2001 \\
\hline$N^{*}$ & Production & Automotive industry & German & 2001 \\
\hline $\mathrm{O}$ & Service & Financial intermediary & Polish & 2010 \\
\hline$P^{*}$ & Production & Automotive industry & Japanese & 2001 \\
\hline $\mathrm{R}$ & Production & Automotive industry & German & 1993 \\
\hline$S$ & Production & Brewing industry & Dutch & 1998 \\
\hline
\end{tabular}

* companies selected for deeper analysis. Source: own elaboration.

Respondents were selected based on the concept of 'elite interviewing', in which interviewees are selected for their experience in an area relevant to the survey [61]. To reach the appropriate respondents, firstly we used the information available on the companies' websites, and then we selected points of contact and asked them to indicate employees who could provide the richest data in relation to our research questions. In this way, in each company, we managed to interview 1 or 2 people responsible for implementing the projects supporting SD goals (usually they were coordinators, experts, consultants or managers, each responsible for CSR, corporate communication or company volunteering programs).

As the study was qualitative in nature, the results (see Section 4) cannot be used to generalize to a larger extent. They may, however, be a starting point for formulating preliminary assumptions or hypotheses for future quantitative research.

\section{Results}

In Section 4.1 we briefly describe all the SD projects indicated by the respondents as the projects undertaken in the surveyed companies in collaboration during the three-year period preceding the interview. In Section 4.2 we focus only on the nine of these joint projects selected as described in the previous section. 


\subsection{Projects Undertaken in Collaboration: Content, Level of Formalization, Duration, Company Partners and Initiator}

The ratio of SD projects carried out independently to those implemented in collaboration varied between the 18 investigated companies. In some companies, the majority (even almost $100 \%$ ) of projects were declared to be implemented in collaboration $(\mathrm{M}, \mathrm{N}, \mathrm{P})$, while in others the ratio was approximately fifty-fifty (G). There was only one company in which, despite cases of collaboration, most of the projects had been undertaken independently during the three-year period preceding the interview $(\mathrm{O})$.

The majority of the projects realized in collaboration were based on cooperation with other organizations, i.e., collective actors: start-ups, companies from the same capital group, local subsidiaries, PR agencies, crowdfunding platforms, hypermarket chains, business partners such as buyers or suppliers, various types of NGOs (mostly external foundations or associations), kindergartens, schools, universities, theaters, sports clubs, chambers of industry and commerce, trade magazines, local police, the city watch, fire brigades, and organizational units of the local or state administration, including departments of urban greenery and forest inspectorates. In the case of collaborations with individual actors, experts in specific topics related to the nature of the project were reported, e.g., specialists in anti-smog solutions, medical experts in oncology or special needs teachers.

Regardless of the type of external partners collaborating with the surveyed companies, the companies' own corporate foundations often participated concurrently in such joint projects (A, B, C, E, G, I, J, O). In such cases, the corporate foundations were usually a kind of intermediary between the company that had created them and its partners, and they took over all or most of the responsibilities in the project undertaken by the company.

The content of the projects undertaken in collaboration concerned solving both environmental and social problems. The projects undertaken independently did not differ significantly in this regard. Nor were most directly consistent with the business profile of the company. Usually, any overlap between their content and the business profile of the company was merely coincidental. Environmental projects undertaken in collaboration involved, for example, planting trees, organizing 'clean up the world' campaigns, conducting ecological education, or organizing ecological competitions. For comparison, the social projects involved various forms of support in solving the problems of specific social groups, such as poor or ill children, the elderly, single mothers, or the unemployed. This took the form of donating money, fund-raising, educating, renovating the interiors and exteriors of institutions serving people in need, etc.

For certain cases, the collaboration with the particular partner was permanent, but in others there was a short-term relationship built to undertake just one specific project. This was primarily determined by the character of the given project-its content indicated what specific actions and resources were essential for its implementation, and thus whether it could be implemented with current partners, or with a new one that was better specialized in a given field.

In some companies, the collaboration within the projects was formalized in contracts (C, E, G, $\mathrm{P})$, and in others it was not formalized and was based only on trust (H, I, L, M). There were also companies in which the level of formalization varied depending on the content of a particular project or the specificity of a partner with which the company was supposed to interact (A, F, K, N).

In some projects, the company was the initiator of the collaboration, but sometimes the initiative came from the other party. This usually depended on the specificity of the project, and hence might have changed, even in the same company, over time. The latter situation happened especially with projects implemented through a company's own foundation. If such a foundation offered a grant program, the initiative often came from partners applying for co-financing of a given project (A, B, C, $G)$. However, the prevailing case was that the company itself proposed an initiative to other parties. Potential partners were sought considering whether they could contribute substantively to a given project (A, B, C, E, F, L, N, P, S). In such cases, the idea for the project first appeared in the company, and then partners were sought for it. The company employees very often played an important role in 
As shown in Table 2, the nine selected projects included both social and environmental ones. None were directly consistent with the business profile of the company.

Interestingly, there were various partners in these collaborations-not only NGOs, but also other companies (business partners), public organizations, local authority units, and even individuals. This might suggest that collaboration in projects supporting SD goals represents a wide range of various relationships, though the situation where the company's partner is another company (business organization) seems to occur less frequently. According to one respondent, the fact of relatively rare collaborations between companies in SD projects may originate from companies competing in undertaking SD activities:

Companies treat their CSR activities as a field of competition, as a factor that makes them distinctive from others-who has a better volunteer program, who has a better artistic program, who has a better idea for charity [...] For precisely this reason, it is difficult for them to collaborate in various areas, because sooner or later there will be a situation where someone [one of the companies] will want to stand out more in a project. (D)

Regardless of the content of the projects, and regardless of the number and types of companies' partners, in most of the analyzed projects there was a minimum of one external NGO involved. This also happened in the cases when the company had its own corporate foundation through which the project was undertaken. This might demonstrate the importance of the participation of external NGOs in projects implemented by companies in collaboration.

\subsubsection{Activities Undertaken and Resources Contributed by Each Partner}

With the aim of describing the nature of the collaborations undertaken within the nine analyzed joint projects, we explored in depth the resources and activities contributed by each partner. The results of this analysis are presented in detail in the Appendix A, and more concisely in Table 3. The data come directly from the respondents' answers and represent their perceptions of the resources and activities contributed by the company and its partners to the joint projects they were asked about during the interview.

Table 3. Main types of resources and activities contributed by companies and their partners in nine analyzed projects (respondents' perceptions).

\begin{tabular}{|c|c|c|}
\hline $\begin{array}{c}\text { Party of } \\
\text { Relationship }\end{array}$ & Resources * & Activities * \\
\hline Company & $\begin{array}{l}\text { work of company volunteers (9), } \\
\text { financial funds for project realization (7), } \\
\text { ideas behind the project (3), company } \\
\text { rooms for project implementation (2), } \\
\text { professional knowledge and experience } \\
\text { (1), gifts for beneficiaries (1) }\end{array}$ & $\begin{array}{l}\text { activities undertaken by company } \\
\text { volunteers-planting trees, renovating zones in } \\
\text { hospitals, reading the therapeutic book, etc. (8), } \\
\text { organizing or co-organizing the project (4), } \\
\text { running internal and external communication (3) }\end{array}$ \\
\hline Partner & $\begin{array}{l}\text { specialist knowledge related to the } \\
\text { project (9), positive image, reputation } \\
\text { (9), voluntary work requiring specialist } \\
\text { skills (8), specialized materials or } \\
\text { equipment needed for project } \\
\text { realization (6), land for project } \\
\text { implementation (2) }\end{array}$ & $\begin{array}{l}\text { preparing, coordinating or supervising the project } \\
\text { (7), collecting, selecting, delivering, buying, } \\
\text { producing materials or equipment needed for } \\
\text { project implementation (6), finding space or } \\
\text { designating land for project implementation (4), } \\
\text { running external communication (3), voluntary } \\
\text { activities undertaken together with company } \\
\text { volunteers (3), training company volunteers (2) }\end{array}$ \\
\hline
\end{tabular}

${ }^{*}$ numbers in brackets indicate in how many of the 9 projects a given activity or resource type was mentioned. Source: own elaboration.

In most of the analyzed projects, the companies collaborated with more than one partner, which might demonstrate that only the synergy of resources and activities contributed by all these partners together enabled the project to be implemented successfully. 
Taking into consideration resources on the company's side, it can be noted that in all nine analyzed projects companies contributed the work of their volunteers. It was also primarily the companies that provided the financial resources to these collaborative initiatives. Thus, they contributed resources related neither to specialist knowledge, nor to the nature of the project. The partners, meanwhile, primarily contributed resources that the companies lacked and/or that were critical to the success of the project-expertise and work requiring specialized skills—as well as specialist material and equipment. Some of the partners, mainly non-profit organizations, additionally contributed their positive image and widely recognized reputation to the project.

Furthermore, a complementarity between the activities undertaken by each partner can be noticed. Companies mostly contributed activities directly related to project realization and those undertaken by their own volunteers. If the nature of the project required it, the company volunteers were first trained by the company's partner or they worked together with its employees to acquire skills vital to the project. As none of the projects were directly consistent with the business profile of the company, the detailed project planning, organization and coordination were usually done by the partner. This might be because most of these partners, and non-profit organizations in particular, have extensive experience in preparing and implementing such projects. The companies' partners, being better specialized in the field of a given project, undertook most of the activities to provide specialized materials and equipment needed for project implementation.

\subsubsection{Actor Bonds in the Process of Initiating and Undertaking the Collaboration}

In most of the nine projects, there were no pre-existing inter-organizational relationships between the company and its partners, nor were there any personal relations between employees on the two sides of the relationship (A, B, G, K, M, N). Nevertheless, the direction in which these personal relations developed during the first meeting of representatives of both sides was important in making the final decision to enter into inter-organizational collaboration. The first contact allowed the company to find out how much the people representing the potential partner shared common values and had a mutual understanding of the goals of the potential collaboration, and whether they were easy enough to get along with:

There were no previous personal contacts with the X foundation, but the first contact turned out to be very important-it showed that on the other side, there are open, warm-hearted people who caught our idea right away. (G)

When there was no history of previous inter-organizational collaboration and, additionally, there was no previous personal contact, the search for partners usually took longer because it required more careful verification of potential candidates for collaboration, from both the legal and the image side:

We checked how the organization was perceived in the environment, whether it was worth doing something with it or there were some problems, for example with accounting or media. $(G)$

In such cases, the partner's search also had a more formal dimension $(\mathrm{E}, \mathrm{L}, \mathrm{N})$. A formal invitation or a request for offers was sent to potential partners, followed by evaluation of the offers and selection of the final partner:

We were looking for substantive competences to implement the action that we assumed. We wanted it to be as transparent as possible. That's why we made inquiries to some organizations and cut a deal with a specific one. (L)

Positive interpersonal relations built during the first meetings were generally favored through all subsequent stages of the analyzed collaborations, from the starting phase, where they helped determine the division of tasks between all parties involved in the project, up to the implementation stage and final evaluation. Maintaining regular contact, including face-to-face meetings between employees involved in implementing the project, even when those people were working from a significant distance, seemed still to be of great importance in all of the analyzed cases: 
People [employees of the two sides] were not easy to meet [due to the distance between them], but it happened that they visited each other, or met somewhere along the way. Sometimes they managed to meet halfway. Maybe it would be enough to only exchange e-mails, but that was not the point. (G)

Interestingly, although respondents recognized the benefits of building positive interpersonal relations from the point of view of the collaboration, the concept of 'good/positive interpersonal relations' was interpreted differently by them. Such relations were described as, on the one hand, ones that did not hinder implementation of the project while at the same time "they did not go beyond professional relations" (A) and, on the other hand, as those that facilitated working in an "informal, pleasant atmosphere" (L) and that evolved into a friendly relationship conducive to building trust and long-term collaboration between organizations $(G)$.

The results of the research indicated the important role of yet another type of personal contact, although it goes beyond the dyadic perspective applied in this article. Here we refer to the personal relations between the company volunteers and the beneficiaries (or employees of the institutions representing the beneficiaries) (e.g., children's homes, special schools, community centers). This kind of personal contact was mainly important when determining the goals and content of the projects undertaken by the company within a corporate volunteer program. The company employees' direct personal contact with the personnel of a given institution or people in need, and hence their proximity (emotional, and also geographical) to specific social or environmental problems, and so on, very often provided the impetus to propose particular projects and partners in their companies (A, E, G, K, $\mathrm{M}, \mathrm{P}, \mathrm{R})$.

\subsection{Positive and Negative Effects of the Collaboration for the Company}

As stated in Section 4.1, each of the 18 investigated companies reported one or more projects undertaken in collaboration (although not all were considered to be the most successful). Referring to them, the respondents were asked about the benefits and any negative effects for the company resulting from such projects in collaboration.

As a result, a wide variety of benefits for the company were indicated. Most of them were associated with the very fact of having undertaken any SD activity at all. In such cases, it was less important for respondents whether the project was carried out independently or in collaboration. The main benefits mentioned were: improving the image of the company, attracting employees with better potential (external employer branding) and increasing business credibility (B, E, F, H, K, L, $\mathrm{M}, \mathrm{N}, \mathrm{P}, \mathrm{S}, \mathrm{R})$. There was also a significant group of benefits related to what the company gained in terms of internal relations. Essentially, there were a number of benefits associated with its own employees, including: increased employee satisfaction and motivation, improvement in relations between employees, better work involvement, internal employer branding, and the appearance of personal benefits (self-esteem, employees' confidence in performing their work duties, sense of pride in their regular job) (B, C, H, I, J, K, L, M, N, O, P, R, S).

The benefits for the company that were genuinely directly related to the collaboration included those essentially associated with the main motives for undertaking the collaboration, i.e., supplementing the company's structure of resources and activities. In this regard, the benefits of obtaining the substantive support required to implement the project (expert knowledge and specialized experience) from the partners were indicated in first place (A, B, E, G, I, K, L, M, N, O, P, S):

The project had a chance to succeed only with the $\mathrm{X}$ foundation, because it was the best expert on this topic. (B)

The analyzed collaboration allowed the companies to achieve the well-known synergy effect (B, E, $\mathrm{G}, \mathrm{H}, \mathrm{L}, \mathrm{M}, \mathrm{N}, \mathrm{O}, \mathrm{P})$. As the respondents pointed out, it was precisely because of collaboration that:

- a larger fund was obtained for implementing the project;

- it was possible to join forces and thus make the project possible (the company employees would not have had time to complete the entire project themselves);

- it was possible to achieve a bigger final effect (e.g., to renovate and furnish more rooms); 
- it was possible to help more beneficiaries;

- the project was implemented in a shorter amount of time because of the division of tasks and the assignment of people with the right competences.

When the company's partner was a local authority entity or a local NGO, it was also noted that its participation helped the project more accurately meet the needs of the local community $(\mathrm{B}, \mathrm{P})$ :

These local foundations know exactly what the local needs and problems are, and how to solve them best [...]. Without them, most of the projects would make no sense or would miss the mark, if we were trying from here [from the position of the company] to determine the best and most useful idea to implement. $(P)$

By undertaking a collaboration with a partner, especially with a well-known NGO or local public institution, it was also possible to increase project credibility in the eyes of the beneficiaries due to the social credibility of this type of organization $(\mathrm{L}, \mathrm{N})$. It was possible to reduce project implementation costs as well, although the company was usually the party that funded the project in terms of resources (see again Table 3). The savings resulted from the lack of need to employ and pay people with qualifications and knowledge in the field of the project. In the case of NGO partners, they usually also assumed the training of company volunteers (as the company had no competence in this area, nor time to undertake the training):

If it weren't for our partner, we would have had to employ additional people to run the project, it would have involved a much larger budget than the transfer of a specific amount of money for the implementation of this project. ( $(E)$

In the case of projects implemented with a business partner, respondents drew attention to the benefits resulting in current and future business collaborations, in the form of the improvement or development of positive relationships with business partner employees, easier communication with them, an increase in mutual trust, and a strengthening of daily co-actions (F, H, L, M, O). Successful collaboration on the project also strengthened the positive image of the company, which helped in building business relationships with new partners, including future contractors and clients from the local market in which the project was implemented (E, L, N):

Compared to projects carried out independently, those done in collaboration have more image-related significance, because partnership gives us greater credibility [...] [by collaboration] we try to differentiate ourselves from competitors [...] we would not have won many tenders if we had not done such projects in collaboration. (L)

The respondents also mentioned the benefits that were associated not so much with further business collaboration as with further collaboration on similar social or environmental projects. As they emphasized, the trust built in implementing one project provided the grounds for deciding whether to implement subsequent projects or to continue the project in subsequent editions in collaboration with the same partner, as well as making it easier to acquire subsequent partners for new projects $(H, M, P)$.

Most respondents did not report any negative effects or costs associated with the analyzed collaboration. If anything was perceived as a source of negative aspects, it was, generally speaking, the need to reconcile the specific nature of the work of all partners. If this specificity was possible to reconcile, the negative effects of collaboration were also avoided. Hence, if negative aspects were indicated, they concerned mainly cases in which NGOs were the company's partners. These are partners that operate differently in many respects from a business entity. When assessing collaborations with NGOs, the respondents emphasized, among other things, that (A, I, L):

- NGOs lack an understanding of the realities of how a business operates;

- NGOs work more slowly than companies; decisions take longer, which may lead to longer preparation time and/or longer project implementation;

- NGOs are not sufficiently prepared to work with volunteers from the company;

- NGOs only want financial resources, not deeper collaboration with companies.

The downsides of collaboration with NGOs may cause some companies to prefer one-off collaborations with NGOs to implement only one joint project. Such one-off collaboration provides the 
companies with the experience and knowledge they previously lacked to implement such projects, thus enabling them to organize further activity on their own:

From the experience we gained [from a partner in the first edition of the project] we are able to actually carry out these activities ourselves, on our own-at least their basic forms [...] Now we need NGOs more to evaluate the program and get their support in how it can be refreshed, but operationally we are able to handle everything without any partner-our internal communication, our HR Department and CSR Office are enough for it. (B)

If some more significant negative aspects were indicated by respondents, they were not associated with the partner but with the authority running the facility (organization) for which activities of the project were being undertaken. In this context, the respondents mainly spoke of such institutions increasing their expectations during the project implementation or in subsequent editions-these expectations went beyond the project scope and were difficult to meet $(G, M)$ :

When we were in these oncology wards for the fifth edition of the therapeutic book project, there were very specific financial expectations [placed upon us] that, since we are already there (and in addition we are a bank), we should have also been financially involved in other hospital departments and have replaced beds, bought equipment, etc. $(G)$

In addition, there were also administrative problems on the part of such institutions which, despite prior arrangements and all project formalities having been completed, resulted in the project not being carried out as intended. This was unsatisfactory not only for the beneficiaries, but also for the volunteers from the company, as it adversely affected their motivation to engage in subsequent projects $(G)$.

Other negative aspects pointed out by the respondents did not specifically relate to collaborative projects, but generally to the involvement of the company's employees in any projects supporting SD goals. Some examples of aspects mentioned in this context are employees involved in projects falling behind on their daily tasks at work $(H, M)$, financial costs related to specific training $(M)$, mental strain among employees because of contact with beneficiaries in need $(\mathrm{J})$, negative comments from non-participating employees towards those who were highly engaged $(\mathrm{H})$, or, as mentioned above, the excessive expectations of the organization receiving help that the project would be continued or go beyond its scope, which put a psychological burden on the employees (M).

\section{Discussion and Conclusions}

Although our research was qualitative in nature, and hence conducted on a small and non-random sample of companies, its results uncover a significant diversity of company partners engaged in such joint co-actions, and a variety of ways of realizing them. Usually the company's partners in such projects are other organizations (collective actors). In such cases, the collaboration can be considered an example of an inter-organizational relationship, just like, for example, a B2B relationship, and therefore a significant number of aspects they share may be indicated. Despite this, our study also lets us indicate some aspects of such a collaboration that make it specific, and thus different from a B2B relationship.

Referring to the dissimilarities, primarily, the nature and content of SD projects undertaken in collaboration are very specific - there is not a direct profit goal when implementing them, including the cases when the company's partner is business-oriented. The collaboration is undertaken to solve particular social and/or environmental problems. Additionally, the choice of collaborative partners essentially depends on the content of the particular project, and not on the economic results of the collaboration. In addition, the recipient of such activities does not pay for the project. In contrast with this, the purpose of each business-to-business relationship is to generate exchange of an economic character. Even if the process contains a large number of social elements, it remains a business interaction due to the economic motivation and outcome of its business exchange [62].

In the next three sections (Sections 5.1-5.3), we present more specific aspects of investigated collaborative initiatives that are common with or different from other types of inter-organizational relationships, and in particular B2B partnerships. The subsections make reference to the four research questions defined in Section 3.1. 


\subsection{Activity Links and Resource Ties}

One of the similarities between investigated inter-organizational relationships and B2B is the exchange of resources and activities between partners as the source of added value. In B2B relationships, two business partners collaborate in order to acquire resources that neither would be able to create easily on their own. They coordinate on a number of exchanges and activities to increase their joint productivity and create a relationship value that is greater than the sum of the individual effects created by each partner $[20,63]$. Analogously, the surveyed companies and their partners enter into a collaboration in order to supplement the lack of specific resources and benefit from complementary activities that would not be possible to carry out alone. It is nevertheless worth pointing out that some dissimilarities in this particular kind of inter-organizational collaboration might also be indicated. They are as follows:

- The companies' partners mostly supplement the companies' resources in terms of specialist knowledge and experience required for project implementation, whilst also contributing to their positive image and widely recognized reputation.

- Companies mostly supplement their partners' resources by providing funds and volunteers.

- Activities undertaken by company employees are usually complemented by their partners in terms of detailed project planning, organization and coordination, and providing necessary specialized materials and equipment.

\subsection{Actor Bonds}

Furthermore, when considering the role of actor bonds in these specific forms of collaboration, some similarities to business-to-business relationships might be noted. According to the ARA model [20], actor bonds, together with activity links and resource ties, are one of the three interrelated layers of the substance of business relationships. Although Håkansson and Snehota [20] do not precisely define 'actor bonds', it could be inferred that they can be also understood as interpersonal interactions between employees representing two organizations, i.e., collective actors making up the two sides of the relationship. In the literature on B2B relationships, such personal interactions are indicated as both the foundation and the result of mutual trust, satisfaction and commitment, through which business-to-business relationships might become a kind of strategic resource, contributing to gaining a competitive advantage $[24,64,65]$. The literature demonstrates that personal bonds might play a very important role in the different stages of B2B relationship building $[20,23,35,66,67]$. A network of personal contacts may be very supportive in establishing a business relationship and might determine whether such a relationship is maintained $[35,68,69]$. When positive, bonds might reduce the degree of formalization $[23,35]$. On the other hand, personal bonds might also be a catalyst for relationship dissolution [70-73].

The company representatives who participated in our research also pointed out the positive role of personal bonds and the importance of mutual interpersonal trust at different stages of the analyzed collaboration. Moreover, a tendency for the level of formalization to fall was mentioned as a consequence of having good (positive) personal contacts. Nevertheless, even when the personal bonds were considered by respondents to be important, their importance was not overestimated, especially at the beginning of the collaboration. Partners were selected for joint projects mainly based on the partner's substantive qualifications (rather than by personal relations). This might demonstrate that a lack of substantive, specialized knowledge, qualifications and experience to run projects independently is the primary reason that companies choose to collaborate with other partners. Such results might support the assumption that, despite the specificity of the collaboration being analyzed in this article, there are similarities with many business-to-business relationships in this regard $[23,36,66]$. It could also suggest that this kind of collaboration is beginning to take a more professional form, just like in business relationships. The selection of potential partners is increasingly being based on professional criteria, which should be no surprise, given that the companies are treating these kinds of initiatives as 
ever more important tools not only for improving their reputation but also for achieving many other goals $[27,39,74-76]$. On the other hand, it seems that the specificity of the analyzed projects does not allow the influence of personal contacts to be eliminated completely. Even if their role might be less important at the stage of searching for a potential partner, it seems still to be crucial at subsequent stages of the project. As respondents pointed out, the direction in which these relations developed during the first meeting between the company and the partner's representative was important in making the final decision to enter into a collaboration. In addition, they indicated that projects can only be successful when the employees on each side of the relationship share common values, have a common vison of how to implement the project, like each other, and are also in regular contact with each other.

\subsection{Effects of the Collaboration for the Company}

Some other similarities and dissimilarities between the considered type of collaboration and B2B relationships might be indicated in their effects for companies. As demonstrated in the article, the respondents indicated a wide variety of positive outcomes of the analyzed collaborations for companies. Many of them (for example, improving company image, attracting employees with better potential, and increasing business credibility) coincide with those described in the literature for any kind of company activity in the area of SD [6,32,39,75-79]. Simultaneously, more general outcomes were indicated that coincide with those indicated by researchers for any type of inter-organizational collaboration, including B2B (supplementing the structure of resources and activities, and thus achieving the synergy effect; development of positive relationships with the partner's employees; improvement of communication with them; an increase in mutual trust, etc.) [80-83]. Nevertheless, it seems that some aspects of the analyzed collaboration might be considered characteristic only of this specific area of a company's activity, and taken into account when assessing its effects; for example, the number of beneficiaries affected by the project undertaken in collaboration, the number of volunteers involved on both sides, the scope or durability of the project's social or environmental impact, the importance of the social or environmental problem being solved.

Similar conclusions can be formulated when analyzing the negative effects of the surveyed collaborations. Some of these outcomes are similar to those indicated for other types of inter-organizational relationships. For example, many of the negative outcomes can be found in the literature on business-to-business relationships [84-86]. Alongside those typical of a business relationship, the outcomes not limited purely to such type of activity but related to the behavior of individuals collaborating on each side of the relationship are also indicated (tension, ill-intended behaviors, opportunistic behavior, unethical practices) [80]. Additionally, in the area of collaborative initiatives undertaken for $\mathrm{SD}$, the literature describes many failures connected with the individuals' behavior, such as an unwillingness to compromise, unrealistic expectations, differing values and goals, inability to cooperate, and inability to understand the otherness of the other [5,87-90]. In this context, the problems related to company-NGO collaboration are relatively often quoted. In actual fact, the results of our study coincide with such findings. Although-according to the respondents-the positive outcomes of the analyzed collaborations definitely outweigh the negative effects, a group of negative aspects for companies were also reported, and most related to collaborations with NGOs. Interestingly, similar allegations of a lack of understanding of the modes of operation or unpreparedness to undertake joint activities are made by representatives of NGOs when asked for an analogous assessment of collaboration with companies (see, e.g., [91,92]). This means that this kind of collaboration-although helpful for companies in their involvement in sustainability—still presents challenges for both parties.

Considering the effects of collaboration, one more similarity can be indicated between the investigated type of inter-organizational relationship and B2B. As the B2B literature states, interactions between two business partners affect not only the resources and activities of the involved companies, but also their interactions with others [48]. This means that third parties to the relationship may 
either take advantage of its development or be negatively affected. In actual fact, we see the same influence when analyzing the collaboration within joint SD projects. The positive effects of such joint initiatives might be beneficial for third parties not directly involved in such a collaboration. Apart from the beneficiaries (who are directly affected by the project), many institutions working with or attending beneficiaries or local authorities might also take advantage of such collaborative initiatives. In the wider context, we can state that the positive benefits of such collaborations might go beyond the analyzed relationships and be noted by the whole of society. On the other hand, the negative effects of such collaborations, too, might be perceived by individuals and organizations not directly involved in the relationship.

\subsection{Theoretical and Practical Contribution}

The article contributes to the literature by deepening the understanding of specific collaborations between companies and other organizations in the field of joint SD projects. It offers a deeper view of such collaborations, focusing on the roles played by each partner and the outcomes that these relationships may generate for companies. Apart from demonstrating the activities and resources contributed to these projects by each partner, we also discuss the role of personal bonds within such inter-organizational relationships. We also explain the specificity of such inter-organizational collaborations and identify to what extent these relationships vary from other types of inter-organizational collaboration-especially from business-to-business relationships. The use of the ARA model in describing this specific collaboration can be also recognized as an original contribution to the theory of inter-organizational relationships. By using the model as the basis for the research and analysis, we were able to demonstrate its usefulness in studies going beyond the context of business-to-business relationships.

There are three main areas in which the article provides practical contributions.

Firstly, it offers a useful framework for analyzing any kind of collaboration, existing or potential; it does not necessarily need to be the type of inter-organizational relationship that is the main subject of this article. As the ARA model takes a somewhat general form, we consider it applicable to studying any kind of collaborative initiative. Moreover, the ARA model can also be used for analyzing the collaboration in the wider context of the network as a whole, which can offer a still more holistic view of how interactions with direct partners and the results of such collaboration are interrelated with other participants in the network as a whole.

Secondly, the article sheds light on the specific kind of inter-organizational relationships built by companies and their partners when undertaking joint projects solving social and/or environmental problems. By indicating examples of company partners engaged in these kind of joint co-actions, the subject areas they covered, the beneficiaries to whom they were addressed, the different ways such collaborations are initiated, and the variety of their organizational dimensions (duration, repeatability, degree of formalization), the article offers guidance for companies and their potential partners (for- and non-profit) interested in undertaking such joint initiatives for sustainability. The detailed presentation of nine selected projects collaborated on by the surveyed companies may be inspiring for other companies undertaking similar initiatives in the future, as we indicated the ways in which the activities and resources of each partner were combined in these projects to make them successful. It may also help organizations decide how to improve the existing combination of resources and activities, both on their side and in the relationships they build with their partners when undertaking joint SD projects.

In this context, we also consider our insights into the role of personal bonds in initiating and undertaking such relationships to be of practical use. The development of interpersonal relationships is very often marginalized, misunderstood or left to chance. Meanwhile, the process of relating to others might be managed, as the process of tying resources and linking activities between collaborating partners is. In the article we demonstrate how the interpersonal bonds between particular employees from each side of the collaboration were developed and used in successful joint projects. Such knowledge might help organizations decide not only how to initiate a collaboration but also how to strengthen 
trust and commitment during the collaboration process. Simultaneously, we indicate the importance of yet another type of interpersonal relationships appearing in this kind of collaboration. We refer to the relations between the company volunteers and the beneficiaries (or employees of institutions that represent the beneficiaries). The results of our study suggest that such personal contacts might determine the success of joint projects, especially when they are undertaken by the company within a corporate volunteer program. They might help to determine the goals and content of projects and make them more fully meet the needs of beneficiaries. Additionally, they might determine the choice of a company's partners in such a collaboration.

The third area of practical implications is related to the effects of implementing projects for SD in collaboration. The positive outcomes presented in the article might be regarded by other companies as a predictor of the potential positive results of such collaboration. Such information may be useful in deciding whether to undertake future SD projects in collaboration or independently. Simultaneously, the indicated aspects of the collaborations that did not provide positive effects for the companies might be practically applicable in deciding about future collaborations. The discussed downsides demonstrate the areas of such inter-organizational collaboration that require special attention from both collaborating partners from the very beginning of the collaborative initiative. As the research results demonstrate, eliminating such downsides increases the chances of a joint project being successful and, moreover, there is a place for developing further high-quality collaboration between partners-both collaboration within the SD area and within business-to-business (with a for-profit partner).

More specifically, within the context of potential downsides, particularly careful consideration should be given to collaboration with external NGOs. On the one hand, an external NGO seems to be the most appropriate company partner for joint projects supporting SD goals. This is because it has specific and unique resources and activities critical to project success not possessed by the company, its corporate foundation or other partners. On the other hand, if any negative aspects of collaboration on SD projects were indicated by respondents, they concerned mainly cases in which an NGO was a collaborative partner. This problem is not a unique occurrence, since the results of our study coincide with those identified by other researchers dealing with the topic of company-NGO collaboration. Hence, it is clear that such troublesome downsides of joint initiatives should not be ignored by potential partners when deciding on future collaborations. Moreover, it is also an important indication for institutions supporting cross-sectoral cooperation. This is even more important in light of the knowledge that most of the negative aspects identified in the study have also been indicated in the literature for years (as demonstrated in the article), and yet seem to be problematic for both parties involved in such relationships.

Returning to projects not just with NGOs but with all types of partner, and focusing on the company perspective, it is also worth suggesting that positive and negative outcomes should be assessed from the point of view both of the whole company and of each involved individual company employee. They include employees involved in the collaboration on the organizational level, as well as those voluntarily committing their time, effort, knowledge, skills and emotions. Misunderstandings with collaborative partners, problems arising from direct contact with beneficiaries in need, or negative attitudes of coworkers not involved in projects might become a heavy psychological burden for such employees, demotivating them and thus possibly also affecting the success of the inter-organizational collaboration. To avoid this, company management should play an important role in solving any kind of problems with collaborative partners. It should motivate employees to participate actively in such projects, build trust among non-participating employees, and offer employees opportunities to develop the skills the projects demand, given that many projects are not based on the competences that professional employees possess. It is also recommended to conduct any kind of summary of the project effects and, after project completion, to give employees the opportunity to share their emotions, experiences and problems encountered.

To sum up, we can state that many different types of practitioners (inside and outside a company) may stand to benefit from our findings, as they may improve insight into the collaboration discussed in 
the article and improve the ability to address collaborative challenges or problems pro-actively, rather than reactively when they occur. Policy-makers, too, are provided a basis for better understanding how the collaboration described in the article works in practice and what kind of outcomes, positive and negative, it offers. It can help them to better adjust their direct policies and resources to support such inter-organizational collaboration for SD.

\subsection{Limitations and Implications for Future Research}

Among the limitations of the research, it should be mentioned that it was qualitative in nature, and that, as a consequence of the type of study, both companies and respondents were selected for it purposively. Additionally, the sample size was relatively small. As a result, it is not possible to generalize the obtained findings to a larger extent. It is also worth noting that our conclusions were based exclusively on interviewee opinions, and that only one or two representative were interviewed for each company. Such opinions may thus be less representative and more influenced by the individual's perspectives, experience of the issues being asked about, and memory; hence, they may not fully and accurately describe the phenomena of interest to us. Choosing a qualitative approach for the study also determined the qualitative nature of the data, which might result in research bias in their classification, comparison, analysis and interpretation. In order to minimize this, more than one researcher was assigned to work on the same empirical material. Additionally, there was one generally binding code book introduced and used by all members of the research team. With the help of such a code book, the transcriptions were independently coded by a minimum of three researchers, and later their results were discussed to reach a consensus, and thus individual subjectivism of interpretation was minimized.

Additionally, it should be noted that the study was conducted among companies operating in Poland, and thus, even if foreign capital prevails in most, their activity in the area of the analyzed collaboration might to some extent reflect conditions specific to Poland. At the same time, they were companies listed in a ranking published by the Responsible Business Forum [93], so they could represent a relatively high level of involvement in various types of activities supporting the achievement of SD goals. It is possible that other companies not selected for the study realize SD projects differently than as described in the article.

It should also be pointed out that the results obtained in this study present the perspective of only one side of the relationship (the company). Admittedly, we tried to overcome this limitation by asking the companies' representatives indirectly about their partners' contribution to the collaboration, and in this way recognize their perspective. However, in such cases, the respondents' answers might be of limited value. This demonstrates that there is a need to obtain dyadic data, which means that research conducted with the representatives of the other side of the collaboration is essential. In this way, the point of view of the second actor in the relationship could be recognized, providing more objective results. We are to some extent conducting such research currently within the same research project (i.e., [94]).

There was also no possibility to demonstrate how respondents defined the term 'successful project', which was used in the study to probe respondents' answers and thus select projects for more extensive analysis. In addition, the respondents were asked for descriptions of projects their company had realized that could be called 'unsuccessful'. Recognizing the reasons for designating such projects 'successful' and 'unsuccessful' could provide a deeper understanding of the perspective of people fully engaged in such projects. Hence, we hope to soon share results on this issue in our further publications.

The article may open new avenues to many other interesting questions closely related to the presented issues. All could be defined as central questions in future research projects, qualitative and/or quantitative. It would be interesting, for example, to examine how to increase the willingness of companies to engage in projects supporting SD goals, and how to increase the willingness of other organizations to collaborate with companies in this field. A study conducted with the companies' partners could deliver answers to questions about the positive and negative effects they can experience from collaborating with companies. In this regard, the contradictory effects related with company-NGO 
collaboration seem to be particularly interesting areas for future research. It could also be interesting to identify the real reasons why collaborating with business partners (other companies) on joint projects is so rare. Taking into account the variety of roles and the importance that the literature assigns to interpersonal interactions created between the employees of two collaborating partners, it could also be interesting to determine in greater detail the role of personal bonds at each stage of the collaborations considered in this article. Specifically, future quantitative research could be conducted, for example, to verify whether the results described in the article differ or coincide when specific types of companies are investigated, i.e., companies representing different sizes (in terms of number of employees or annual revenues), different fields of activity (sector, industry), or other features with a potential impact on companies' propensity toward involvement in SD (see, e.g., [79,95-97]). It would also be interesting to broaden the geographical scope of the research, and thus verify to what extent the results obtained in Polish conditions may coincide with the findings obtained in other countries. The literature review led us to expect that many differences in this regard could be found due to different market conditions for companies' activities or social expectations of business's contribution to resolving environmental and social problems. Moreover, the companies' partners within joint SD projects, including NGOs, may have to deal in countries with different institutional environment and socio-cultural factors to those in Poland (see, e.g., [98-102]), and thus the nature of their collaboration and the obtained results may also be different than in Poland.

Author Contributions: I.E. and P.B. contributed to the research design and collection of qualitative data (with the participation of other members of the research team); I.E. and P.B. conducted the literature review; I.E. prepared the draft of Introduction, Section 2, Section 3, Section 4 and the Discussion and Conclusions section; I.E. and P.B. performed the analysis and interpretation of data, and also wrote the paper. All authors have read and agreed to the published version of the manuscript.

Funding: The project was funded by the National Science Center, Poland, on decision number DEC-2017/25/ B/HS4/01113.

Acknowledgments: The paper was developed as part of the project "Positive social change in the organization as a factor of company involvement in the implementation of sustainable development". The project was funded by the National Science Center, Poland, on decision number DEC-2017/25/B/HS4/01113. The authors would like to thank the other members of the research team who cooperated in this project and all the respondents for their participation in the conducted study.

Conflicts of Interest: The authors declare no conflict of interest. The funder had no role in the design of the study; the collection, analysis, and interpretation of data; the writing of the manuscript; or the decision to publish the results.

\section{Appendix A}

Table A1. Resources and activities contributed by companies and their partners in the nine analyzed projects (respondents' perceptions).

\begin{tabular}{|c|c|c|c|}
\hline $\begin{array}{l}\text { Project } \\
\text { Name }\end{array}$ & $\mathbf{R} / \mathbf{A}^{*}$ & $\begin{array}{l}\text { Company/ } \\
\text { Partner }\end{array}$ & Description \\
\hline \multirow{4}{*}{ 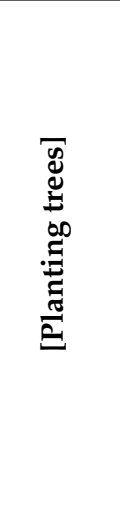 } & \multirow[b]{2}{*}{$\mathbf{R}$} & Company & $\begin{array}{l}\text { work of company volunteers, funds for buying seedlings, shovels and hot } \\
\text { drinks for volunteers }\end{array}$ \\
\hline & & Partner & $\begin{array}{l}\text { work of foundation volunteers, professional knowledge about planting trees, } \\
\text { specialized materials/equipment needed for project realization, positive } \\
\text { image (external NGO); land for project implementation (public organization) }\end{array}$ \\
\hline & \multirow{2}{*}{ A } & Company & $\begin{array}{l}\text { organizing the project, preparing internal messages for employees, } \\
\text { communicating in social media, renting a bus to transport company } \\
\text { volunteers; planting trees (company volunteers) }\end{array}$ \\
\hline & & Partner & $\begin{array}{l}\text { coordinating the project, advising on seedling selection, helping with } \\
\text { planting trees, buying seedlings, buying shovels, communicating in social } \\
\text { media (external NGO); designating land for project implementation } \\
\text { (public organization) }\end{array}$ \\
\hline
\end{tabular}


Table A1. Cont.

\begin{tabular}{|c|c|c|c|}
\hline $\begin{array}{l}\text { Project } \\
\text { Name }\end{array}$ & $\mathbf{R} / \mathbf{A}^{*}$ & $\begin{array}{l}\text { Company/ } \\
\text { Partner }\end{array}$ & Description \\
\hline \multirow{4}{*}{ 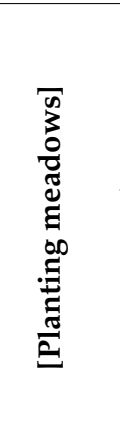 } & \multirow[b]{2}{*}{$\mathbf{R}$} & Company & work of company volunteers, funds for project realization \\
\hline & & Partner & $\begin{array}{l}\text { expertise in sowing melliferous flower meadows, seeds and plants to be } \\
\text { planted, equipment used when planting meadows, reputation } \\
\text { (external NGO) }\end{array}$ \\
\hline & \multirow{2}{*}{ A } & Company & $\begin{array}{l}\text { promoting the idea of a project among own employees, choosing a partner } \\
\text { for project realization and conducting a dialogue with the partner } \\
\text { (corporate foundation) }\end{array}$ \\
\hline & & Partner & $\begin{array}{l}\text { seed and plant production, delivery of seeds, plants and equipment to the } \\
\text { place of project implementation (external NGO); designation of land for } \\
\text { project implementation (public organization) }\end{array}$ \\
\hline \multirow{4}{*}{ 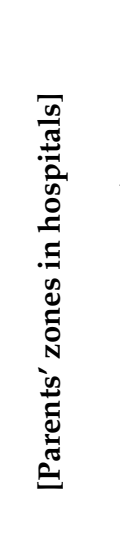 } & \multirow[b]{2}{*}{$\mathbf{R}$} & Company & the idea of the project, funds for realization, work of company volunteers \\
\hline & & Partner & $\begin{array}{l}\text { expertise in volunteering projects and voluntary work with ill children (PR } \\
\text { agency); work on the project (PR agency, famous actress); positive image } \\
\text { (famous actress) }\end{array}$ \\
\hline & \multirow[b]{2}{*}{ A } & Company & $\begin{array}{l}\text { choosing a hospital (beneficiary) for each edition, recruiting workers to } \\
\text { implement the project (to do a renovation) among company employees; } \\
\text { renovating and furnishing parents' zones in hospitals (company volunteers) }\end{array}$ \\
\hline & & Partner & $\begin{array}{l}\text { administrative assistance, preparing the concept and designing the } \\
\text { arrangement of the zone, contact with the hospital selected by the company, } \\
\text { selection of a specific space in the hospital for the parents' zone, training for } \\
\text { company volunteers (preparing them for direct contact with ill children) (PR } \\
\text { agency); participation in the opening ceremony of the zone; being the project } \\
\text { ambassador (famous actress) }\end{array}$ \\
\hline \multirow{4}{*}{ 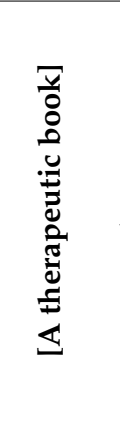 } & \multirow[b]{2}{*}{$\mathbf{R}$} & Company & $\begin{array}{l}\text { the idea of the project (book), funds for book printing, work of } \\
\text { company volunteers }\end{array}$ \\
\hline & & Partner & $\begin{array}{l}\text { professional knowledge, therapeutic texts and materials used to write the } \\
\text { book, reputation (external NGO); work on the project (external NGO, } \\
\text { famous individuals) }\end{array}$ \\
\hline & \multirow[b]{2}{*}{ A } & Company & $\begin{array}{l}\text { reading the book in hospitals (company volunteers); responding to requests } \\
\text { and sending the book to those interested in it (corporate foundation) }\end{array}$ \\
\hline & & Partner & $\begin{array}{l}\text { providing the novelist factual assistance when writing the book (external } \\
\text { NGO); writing the book (a novelist); reading the book in hospitals } \\
\text { (famous individuals) }\end{array}$ \\
\hline
\end{tabular}

\begin{tabular}{|c|c|c|c|}
\hline $\bar{v}$ & & Company & work of company volunteers, company rooms for workshops \\
\hline 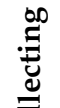 & & Partner & $\begin{array}{l}\text { professional knowledge of fairytale therapy, work of foundation volunteers, } \\
\text { positive image (external NGO) }\end{array}$ \\
\hline שֶ & & Company & $\begin{array}{l}\text { collecting books for ill children, visiting ill children in hospitals, reading } \\
\text { books in hospitals (company volunteers) }\end{array}$ \\
\hline 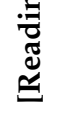 & $\pi$ & Partner & $\begin{array}{l}\text { collecting books for ill children, equipping libraries in hospitals, preparing } \\
\text { company volunteers for reading to ill children, communicating in social } \\
\text { media (external NGO) }\end{array}$ \\
\hline
\end{tabular}


Table A1. Cont.

\begin{tabular}{|c|c|c|c|}
\hline \multirow{4}{*}{ 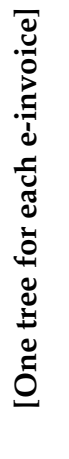 } & \multirow[b]{2}{*}{$\mathbf{R}$} & Company & funds to buy seedlings, work of company volunteers \\
\hline & & Partner & $\begin{array}{l}\text { work of foundation volunteers, professional knowledge of planting trees, } \\
\text { specialized equipment needed for project realization, positive image } \\
\text { (external NGO) }\end{array}$ \\
\hline & \multirow[b]{2}{*}{ A } & Company & $\begin{array}{l}\text { co-organizing the project, organizing transport; planting trees } \\
\text { (company volunteers) }\end{array}$ \\
\hline & & Partner & $\begin{array}{l}\text { finding a place for planting, negotiating with local authorities, organizing } \\
\text { catering for company volunteers, selecting seedlings, buying seedlings, } \\
\text { delivering seedlings to the place of planting, calculating carbon dioxide } \\
\text { absorption of planted trees (external NGO) }\end{array}$ \\
\hline \multirow{4}{*}{ 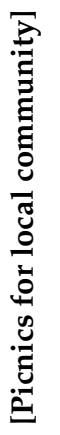 } & \multirow[b]{2}{*}{$\mathbf{R}$} & Company & funds, work of company volunteers \\
\hline & & Partner & $\begin{array}{l}\text { work of association volunteers, professional knowledge, specialized } \\
\text { equipment for project realization, reputation (NGO); trucks and drivers } \\
\text { (for-profit organizations) }\end{array}$ \\
\hline & \multirow{2}{*}{ A } & Company & $\begin{array}{c}\text { organizing integration meetings, inviting suppliers and } \\
\text { customers to meetings }\end{array}$ \\
\hline & & Partner & $\begin{array}{l}\text { co-organizing integration meetings (external NGO); presenting trucks, } \\
\text { sharing knowledge about safety in transport (for-profit organizations) }\end{array}$ \\
\hline \multirow{4}{*}{ 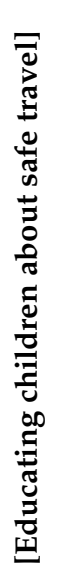 } & \multirow{2}{*}{$\mathbf{R}$} & Company & $\begin{array}{c}\text { work of company volunteers, professional knowledge and experience, room } \\
\text { with car seats, contest prizes, gifts for children }\end{array}$ \\
\hline & & Partner & $\begin{array}{l}\text { professional knowledge and experience, positive image of the police, } \\
\text { specialized materials/equipment needed for project realization } \\
\text { (public organization) }\end{array}$ \\
\hline & \multirow[t]{2}{*}{ A } & Company & $\begin{array}{l}\text { organizing workshops (sending invitations, preparing the room with car } \\
\text { seats), talking with children about safety, displaying educational films, } \\
\text { teaching children how to fasten seatbelt, organizing contest with prizes }\end{array}$ \\
\hline & & Partner & $\begin{array}{l}\text { educating children about road safety, presenting a police car to children } \\
\text { (public organization) }\end{array}$ \\
\hline \multirow{4}{*}{ 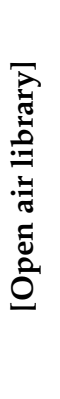 } & \multirow[b]{2}{*}{$\mathbf{R}$} & Company & funds for the project and its realization, work of company volunteers \\
\hline & & Partner & $\begin{array}{l}\text { professional knowledge, work of students preparing the project, work of a } \\
\text { teacher supervising the project, reputation (public organization) }\end{array}$ \\
\hline & $\mathbf{A}$ & Company & $\begin{array}{l}\text { recruiting company volunteers, formulating project evaluation criteria, } \\
\text { setting a schedule (company foundation); installing benches, boxes and other } \\
\text { equipment in the open-air library (company volunteers) }\end{array}$ \\
\hline & $\mathbf{A}$ & Partner & $\begin{array}{l}\text { preparing, coordinating and supervising the project, consulting, arranging } \\
\text { space (public organization); coordinating the project, managing financial } \\
\text { funds (external NGO) }\end{array}$ \\
\hline
\end{tabular}

${ }^{*} \mathbf{R}$-contributed resources, $\mathbf{A}$-contributed activities. Source: own elaboration. 


\section{References}

1. United Nations. Problems of the Human Environment: Report of the Secretary-General; UN: New York, NY, USA, 1969; pp. 1-66.

2. Meadows, D.H.; Meadows, D.L.; Randers, J.; Behrens, W.W. The Limits to Growth; Universe Books: New York, NY, USA, 1972; pp. 1-205.

3. Brundtland, G.H. Report of the World Commission on Environment and Development: Our Common Future; UN: New York, NY, USA, 1987; pp. 1-374. Available online: http://www.un-documents.net (accessed on 12 July 2019).

4. Eccles, R.G.; Miller Perkins, K.; Serafeim, G. How to Become a Sustainable Company. MIT Sloan Manag. Rev. 2012, 53, 43-50.

5. Borg, J.; Yström, A. Collaboration for Sustainable Development: Interrelating Practice and Challenges. In Proceedings of the ISPIM Innovation Forum, Boston, MA, USA, 25-28 March 2018; pp. 1-18.

6. Peloza, J.; Falkenberg, L. A Framework for Firm-NGO Collaboration; The annual conference proceedings ASAC: Ottawa, ON, Canada, 2007; pp. 6-21. Available online: https://www.researchgate.net/publication/237678166_ A_Framework_for_Firm-NGO_Collaboration (accessed on 30 June 2019).

7. Gutiérrez Aguilar, C.M.; Panameño, R.; Perez Velazquez, A.; Angel Álvarez, B.E.; Kiperstok, A.; César, S.F. Cleaner Production Applied in a Small Furniture Industry in Brazil: Addressing Focused Changes in Design to Reduce Waste. Sustainability 2017, 9, 1867. [CrossRef]

8. Galpin, T.; Whittington, J.L.; Bell, G. Is your sustainability strategy sustainable? Creating a culture of sustainability. Corp. Gov. 2015, 15, 1-17. [CrossRef]

9. Adda, G.; Bosco Azigwe, J.; Awuni, A.R. Business Ethics and Corporate Social Responsibility for Business Success and Growth. Eur. J. Bus. Innov. Res. 2016, 4, 26-42.

10. Navajas, A.; Uriarte, L.; Gandía, L.M. Application of eco-design and life cycle assessment standards for environmental impact reduction of an industrial product. Sustainability 2017, 9, 1724. [CrossRef]

11. Brzustewicz, P. Marketing zrównoważony jako nowoczesna koncepcja zarządzania produktem. In Wspótczesne Zarzadzanie: Różnorodność Problemów i Sposobów Ich Rozwiązywania; Gonciarski, W., Ornarowicz, U., Eds.; Wojskowa Akademia Techniczna w Warszawie: Warszawa, Poland, 2013; pp. 119-134.

12. Peloza, J.; Hassay, D.N. Intra-organizational volunteerism: Good soldiers, good deeds and good politics. J. Bus. Ethics 2006, 64, 357-379. [CrossRef]

13. Gordon, L.; Wai-Wai, K. Social Alliance and Employee Voluntary Activities: A Resource-Based Perspective. J. Bus. Ethics 2011, 104, 251-268. [CrossRef]

14. Dreesbach-Bundy, S.; Scheck, B. Corporate volunteering: A bibliometric analysis from 1990 to 2015. Bus. Ethics 2017, 26, 240-256. [CrossRef]

15. Gómez Santos, P.; Fernández Fernández, J.L. Motivations and possible decisive factors in employee participation in corporate volunteering programmes. Ramon Llull J. Appl. Ethics 2017, 8, 121-157.

16. Rodell, J.B.; Booth, J.E.; Lynch, J.W.; Zipay, K.P. Corporate volunteering climate-mobilizing employee passion for societal causes and inspiring future charitable action. Acad. Manag. J. 2017, 60, 1662-1681. [CrossRef]

17. Herrera, J.; De las Heras-Rosas, C. Corporate Social Responsibility and Human Resource Management: Towards Sustainable Business Organizations. Sustainability 2020, 12, 841. [CrossRef]

18. Van Zanten, J.A.; Van Tulder, R. Multinational Enterprises and the Sustainable Development Goals: An Institutional Approach to Corporate Engagement. J. Int. Bus. Policy 2018, 1, 208-233. [CrossRef]

19. Jayaratne, M.; Sullivan Mort, G.; D'Souza, C. Sustainability Entrepreneurship: From Consumer Concern Towards Entrepreneurial Commitment. Sustainability 2019, 11, 7076. [CrossRef]

20. Håkansson, H.; Snehota, I. Developing Relationships in Business Networks; Routledge: London, UK; New York, NY, USA, 1995; pp. 1-433.

21. Biggemann, S.; Buttle, F. Conceptualising business-to-business relationship value. Presented at the 21st IMP Conference, Rotterdam, The Netherlands, 1-3 September 2005. Available online: http://impgroup.org/ uploads/papers/4667.pdf (accessed on 14 July 2019).

22. Shaladi, B. Business relationship development and the influence of psychic distance. Innov. Mark. 2012, 8, 73-80. 
23. Glinska-Newes, A.; Escher, I.; Brzustewicz, P.; Szostek, D.; Petrykowska, J. Relationship-focused or deal-focused? Building interpersonal bonds within B2B relationships. Balt. J. Manag. 2018, 13, 508-527. [CrossRef]

24. Morgan, R.M.; Hunt, S.D. The Commitment-Trust Theory of Relationship Marketing. J. Mark. 1994, 58, 20-38. [CrossRef]

25. Glińska-Neweś, A.; Brzustewicz, P.; Escher, I.; Fomina, Y.; Józefowicz, B.; Katunina, I.; Petrykowska, J.; Szostek, D. Company Involvement in Sustainable Development-Proposition of a Theoretical Framework. In Contemporary Challenges in Cooperation and Coopetition in the Age of Industry 4.0; Zakrzewska-Bielawska, A., Staniec, I., Eds.; Springer Proceedings in Business and Economics, Springer: Cham, Switzerland, 2020; pp. 439-451. [CrossRef]

26. Austin, J.E. Strategic collaboration between nonprofits and businesses. Nonprof. Volunt. Sec. Q. 2000, 29, 69-97. [CrossRef]

27. Austin, J.E.; Seitanidi, M.M. Collaborative Value Creation: A Review of Partnering Between Nonprofits and Businesses. Part II: Partnership Processes and Outcomes. Nonprof. Volunt. Sec. Q. 2012, 41, 929-968. [CrossRef]

28. AL-Tabbaa, O.; Leach, D.; March, D. Collaboration between nonprofit and business sectors: A framework to guide strategy development for nonprofit organizations. Voluntas Int. J. Volunt. Nonprofit Organ. 2014, 25, 657-678. [CrossRef]

29. Austin, J.E.; Seitanidi, M.M. Collaborative Value Creation: A Review of Partnering Between Nonprofits and Businesses: Part I: Value Creation Spectrum and Collaboration Stages. Nonprof. Volunt. Sec. Q. 2012, 41, 726-758. [CrossRef]

30. Booth, J.; Won Park, K.; Glomb, T. Employer-supported volunteering benefits, gift exchange among employers, employees and volunteer organizations. Hum. Resour. Manag. 2009, 48, 227-249. [CrossRef]

31. Lee, L. Corporate volunteering: Considering multiple stakeholders. Third Sect. Rev. 2010, 16, 87-104.

32. Samuel, O.; Wolf, P.; Schilling, A. Corporate Volunteering. Benefits and Challenges for Nonprofits. Nonprofit Manag. Lead. 2013, 24, 163-179. [CrossRef]

33. Austin, J.E.; Seitanidi, M.M. Creating vAlue in Nonprofit-Business Collaborations. New Thinking and Practice; Jossey-Bass: San Francisco, CA, USA, 2014; pp. 1-320.

34. Håkansson, H. International Marketing and Purchasing of Industrial Good-An. Interaction Approach; John Wiley \& Sons Ltd.: London, UK, 1982; pp. 1-416.

35. Gesteland, R.R. Cross-Cultural Business Behavior: A Guide for Global Management; Copenhagen Business School Press: Copenhagen, Denmark, 2012; pp. 1-400.

36. Escher, I.; Brzustewicz, P. Przejawy podejścia protransakcyjnego i propartnerskiego w relacjach biznesowych budowanych na polskim rynku. Hand. Wewn. 2018, 376, 53-63.

37. Gebert-Persson, S.; Mattsson, L.-G.; Öberg, C. The network approach-a theoretical discussion. Presented at the 30th IMP Conference, Bordeaux, France, 1-6 September 2014; pp. 1-34. Available online: https: //www.impgroup.org/uploads/papers/8198.pdf (accessed on 8 December 2019).

38. Lenney, P.; Easton, G. Actors, resources, activities and commitments. Ind. Market. Manag. 2009, 38, 553-561. [CrossRef]

39. Enright, S.; Oger, C.; Pruzan-Jorgensen, P.M.; Farrag-Thibault, A. Private-Sector Collaboration for Sustainable Development. Research Report; The Rockefeller Foundation \& BSR: San Francisco, CA, USA, 2018; pp. 1-48. Available online: https://www.bsr.org/reports/BSR_Rockefeller_Private-Sector_Collaboration_for_ Sustainable_Development.pdf (accessed on 20 August 2019).

40. Laszlo, C. Firma Zrównoważonego Rozwoju; Wydawnictwo Studio Emka: Warszawa, Poland, 2008; pp. 1-247.

41. Zieni, B.; Chitchyan, R.; Heckel, R. Trust as a Sustainability Requirement, CEUR Workshop Proceedings. In Proceedings of the 6th International Workshop on Requirements Engineering for Sustainable Systems, Lisboa, Portugal, 4 September 2017; pp. 1-3. Available online: http://ceur-ws.org/Vol-1944/paper3.pdf (accessed on 10 August 2019).

42. Doda, S. The Importance of Corporate Social Responsibility. J. Sociol. Res. 2015, 6, 86-91. [CrossRef]

43. Azapagic, A. Systems Approach to Corporate Sustainability: A General Management Framework. Process. Saf. Environ. 2003, 81, 303-316. [CrossRef]

44. Epstein, M.J. Making Sustainability Work. Best Practices in Managing and Measuring Corporate Social, Environmental, and Economic Impacts; Greenleaf Publishing Limited: Sheffield, UK, 2008; pp. 1-308. 
45. Łapińska, J.; Escher, I.; Kądzielawski, G.; Brzustewicz, P. Environmental aspects of sustainable development in the cement industry: Activities communicated by enterprises functioning in Poland. Cem. Wapno Beton 2019, 22, 267-275. [CrossRef]

46. Łapińska, J.; Escher, I.; Kądzielawski, G.; Brzustewicz, P. Social activities for sustainable development in the cement industry in Poland-good practice. Cem. Wapno Beton 2019, 24, 462-470. [CrossRef]

47. Dahlsrud, A. How Corporate Social Responsibility is Definied: An Analysis of 37 Definitions. Corp. Soc. Resp. Env. Ma. 2008, 15, 1-13. [CrossRef]

48. United Nations. Transforming Our World: The 2030 Agenda for Sustainable Development; UN: New York, NY USA, 2015; pp. 1-35. Available online: https://sustainabledevelopment.un.org (accessed on 10 June 2019).

49. Waluszewski, A.; Ford, D.; Håkansson, H.; Snehota, I.; Gadde, L.-E. Analysing business interaction. Presented at the 24th IMP Conference, Uppsala, Sweden, 4-6 September 2008; pp. 1-37. Available online: https://www.impgroup.org/uploads/papers/6707.pdf (accessed on 10 December 2019).

50. Ford, D.; Gadde, L.-E.; Hakansson, H.; Snehota, I. Managing Business Relationships, 3rd ed.; John Wiley \& Sons Ltd.: Hoboken, NJ, USA, 2011; pp. 1-252.

51. Munksgaard, K.B.; Ford, D. The idea of the interacting business actor. Presented at the 30th IMP Conference, Bordeaux, France, 1-6 September 2014; pp. 1-31. Available online: https://www.impgroup.org/uploads/ papers/8250.pdf (accessed on 10 December 2019).

52. Ratajczak-Mrozek, M.; Herbeć, M. Actors-Resources-Activities analysis as a basis for Polish furniture network. Drewno 2013, 56, 115-137. [CrossRef]

53. McDaniel, C.; Gates, R. Marketing Research, 10th ed.; Wiley: Hoboken, NJ, USA, 2015; pp. 1-624.

54. Parasuraman, A.; Dhruv, G.; Krishnan, R. Marketing Research, 2nd ed.; Houghton Mifflin: Boston, MA, USA, 2007; pp. 1-672.

55. Park, J.; Park, M. Qualitative versus Quantitative Research Methods: Discovery or Justification? J. Mark. Thought 2016, 3, 1-7. [CrossRef]

56. Ritchie, J.; Lewis, J. (Eds.) Qualitative Research Practice: A Guide for Social Science Students and Researcher; SAGE Publications: London, UK, 2003; pp. 1-335.

57. Mack, N.; Woodsong, C.; Macqueen, K.M.; Guest, G.; Namey, E. Qualitative Research Methods: A Data Collector's Field Guide; Family Health International: Research Triangle Park, NC, USA, 2005; pp. 1-120.

58. Tull, D.S.; Hawkins, D.I. Marketing research. Measurement and Method; Macmillan Publ. Co.: New York, NY, USA; Collier Macmillan Publ.: London, UK, 1987; pp. 1-845.

59. Guest, G.; Bunce, A.; Johnson, L. How many interviews are enough? An experiment with data saturation and variability. Field Method 2006, 18, 59-82. [CrossRef]

60. Saunders, B.; Sim, J.; Kingstone, T.; Baker, S.; Waterfield, J.; Bartlam, B.; Burroughs, H.; Jinks, C. Saturation in qualitative research: Exploring its conceptualization and operationalization. Qual. Quant. 2017, 52, 1893-1907. [CrossRef]

61. Marshall, C.; Rossman, G.B. Designing Qualitative Research; Sage Publications: London, UK, 1989; pp. 1-263.

62. Prenkert, F. Business Relationships as Activity Systems-A Conceptual Note. Presented at the 16th IMP Conference, Bath, UK, 7-9 September 2000; pp. 1-16. Available online: https:/www.impgroup.org/uploads/ papers/106.pdf (accessed on 29 December 2019).

63. Holm, D.B.; Eriksson, K.; Johanson, J. Creating value through mutual commitment to business network relationships. Strateg. Manag. J. 1999, 20, 467-486. [CrossRef]

64. Crosby, L.A.; Evans, K.R.; Cowles, D. Relationship Quality in Services Selling: An Interpersonal Influence Perspective. J. Market. 1990, 54, 68-81. [CrossRef]

65. Storbacka, K.; Strandvik, T.; Grönroos, C. Managing customer relationships for profit: The dynamics of relationship quality. Int. J. Serv. 1994, 5, 21-38. [CrossRef]

66. Glińska-Neweś, A.; Sudolska, A.; Escher, I. Więzi osobiste jako komponent relacji biznesowych w ocenie reprezentantów polskich przedsiębiorstw. Prace Nauk. Uniw. Ekon. We Wroc. 2016, 444, 140-149. [CrossRef]

67. Glińska-Neweś, A.; Petrykowska, J.; Escher, I.; Brzustewicz, P. Kulturowe uwarunkowania budowania relacji B2B. Market. Rynek 2017, 24, 116-121.

68. Jansson, H.A.; Johanson, M.; Ramstrom, J. Institutions and networks: Business networks in the Chinese, Russian, and West-European institutional contexts. J. Ind. Market. Manag. 2007, 36, 955-967. [CrossRef] 
69. Ivanova-Gongne, M. Culture in Business Interaction: An. Individual Perspective. Empirical studies in Finnish-Russian Business Relationships. Ph.D. Thesis, School of Business and Economics Åbo Akademi University, Turku, Finland, 2014; pp. 1-93.

70. Halinen, A.; Salmi, A. Managing the informal side of business interaction: Personal contacts in the critical phases of business relationships. Presented at the 17th IMP Conference, Oslo, Norway, 9-11 September 2001; pp. 1-20. Available online: http://impgroup.org/uploads/papers/188.pdf (accessed on 25 June 2019).

71. Tähtinen, J. The Dissolution Process. of a Business Relationship. A Case Study from Tailored Software Business; Publications of the Oulu University: Oulu, Finland, 2001; pp. 1-282.

72. Gedeon, I.M.; Fearne, A.; Poole, N. The role of inter-personal relationships in the dissolution of business relationships. J. Bus. Ind. Mark. 2009, 24, 218-226. [CrossRef]

73. Escher, I.; Glińska-Neweś, A.; Brzustewicz, P. Znaczenie osobistych więzi partnerów relacji biznesowej na etapie jej kończenia. Organ. Kier. 2017, 176, 269-283.

74. Kiron, D.; Kruschwitz, N.; Haanaes, K.; Reeves, M.; Fuisz-Kehrbach, S.-K.; Kell, G. Joining Forces: Collaboration and Leadership for Sustainability, Research Report by MIT Sloan Management Review, The Boston Consulting Group and the United Nations Global Compact. 2015. Available online: https://www.unglobalcompact.org/docs/publications/Joining_Forces_MITSMR_BCG_ UNGlobalCompact_Report.pdf (accessed on 7 July 2019).

75. Pedersen, E.R.; Pedersen, J.T. The Rise of Business-NGO Partnerships. J. Corp. Citizensh. 2013, 50, 6-19. [CrossRef]

76. Damlamian, C. Corporate-NGO Partnerships for Sustainable Development. CUREJ Coll. Undergrad. Res. Electron. J. 2006, 1-51. Available online: http://repository.upenn.edu/curej/12 (accessed on 11 August 2019).

77. Dahan, N.M.; Doh, J.P.; Oetzel, J.; Yaziji, M. Corporate-NGO Collaboration: Co-creating New Business Models for Developing Markets. Long Range Plan. 2010, 43, 326-342. [CrossRef]

78. Kitzman, K. The Need for Cooperation between Enterprises and Non-governmental Organizations. Zarzadzanie Publiczne 2015, 32, 313-324.

79. Stekelorum, R.; Laguir, I.; Elbazc, J. Cooperation with international NGOs and supplier assessment: Investigating the multiple mediating role of CSR activities in SMEs. Ind. Mark. Manag. 2020, 84, 50-62. [CrossRef]

80. Nohria, N.; Garcia-Pont, C. Global strategic linkages and industry structure. Strateg. Manag. J. Summer Spec. Issue 1991, 12, 105-124. [CrossRef]

81. Gulati, R. Alliances and networks. Strateg. Manag. J. 1998, 19, 293-317. [CrossRef]

82. Ahuja, G. The duality of collaboration: Inducements and opportunities in the formation of inter-firm linkages. Strateg. Manag. J. 2000, 21, 317-343. [CrossRef]

83. Bititci, U.; Turner, T.; Mackay, D.; Kearney, D.; Parung, J.; Walters, D. Managing synergy in collaborative enterprises. Prod. Plan. Control. 2007, 18, 454-465. [CrossRef]

84. Ariño, A.; De la Torre, J. Learning from failure: Towards an evolutionary model of collaborative ventures. Organ. Sci. 1998, 9, 306-325. [CrossRef]

85. Abosag, I.; Yen, D.A.; Barnes, B.R. What is dark about the dark-side of business relationships? Ind. Market. Manag. 2016, 55, 5-9. [CrossRef]

86. Oliveira, N.; Lumineau, F. The Dark Side of Interorganizational Relationships: An Integrative Review and Research Agenda. J. Manag. 2019, 45, 231-261. [CrossRef]

87. Bramwell, B.; Lane, B. Collaboration and partnerships in tourism planning. In Tourism Collaboration and Partnerships: Politics, Practice and Sustainability; Bramwell, B., Lane, B., Eds.; Channel View Publications: Clevedon, UK, 2000; pp. 1-19.

88. Halme, M. Learning for sustainable development in tourism networks. Bus. Strateg. Environ. 2001, 10, 100-114. [CrossRef]

89. Brandstetter, R.; De Bruijn, H.; Byrne, M.; Deslauriers, H.; Förschner, M.; Machačová, J.; Orologa, A.; Scoppetta, A. Successful Partnerships. A Guide; Forum on Partnerships and Local Governance, OECD LEED at ZSI (Centre for Social Innovation): Vienna, Austria, 2006; pp. 1-36.

90. Poret, S. Corporate-NGO Partnerships through Sustainability Labeling Schemes: Motives and Risks. Sustainability 2019, 11, 2689. [CrossRef]

91. Selsky, J.W.; Parker, B. Cross-sector partnerships to address social issues: Challenges to theory and practice. J. Manag. 2005, 31, 849-873. [CrossRef] 
92. Mirońska, D.; Zaborek, P. NGO-Business Collaboration: A Comparison of Organizational, Social, and Reputation Value From the NGO Perspective in Poland. Nonprof. Volunt. Sec. Q. 2018, 48, 532-551. [CrossRef]

93. Forum Odpowiedzialnego Biznesu. Available online: http://odpowiedzialnybiznes.pl (accessed on 10 June 2019).

94. Brzustewicz, P.; Escher, I.; Hermes, J.; Ulkuniemi, P. Collaborating to do good-analysis of relationships between companies and nonprofit organizations in the field of corporate volunteering. Presented at the 35th IMP Conference, Paris, France, 27-31 August 2019. Available online: https:/www.impgroup.org/uploads/ papers/11027.pdf (accessed on 26 October 2019).

95. Lewis, K.V.; Cassells, S.; Roxas, H. SMEs and the potential for a collaborative path to environmental responsibility. Bus. Strategy Environ. 2015, 24, 750-764. [CrossRef]

96. Russo, A.; Tencati, A. Formal vs. informal CSR strategies: Evidence from Italian micro, small, medium-sized, and large firms. J. Bus. Ethics 2009, 85, 339-353. [CrossRef]

97. Laguir, I.; Laguir, L.; Elbaz, J. Are family small-and medium-sized enterprises more socially responsible than nonfamily small-and medium-sized enterprises? Corp. Soc. Resp. Environ. Manag. 2016, 23, 386-398. [CrossRef]

98. Cumming, G.D. French NGOs in the Global Era: Professionalization "Without Borders"? Volunt. Int. J. Volunt. Nonprofit Organ. 2008, 19, 372-394. [CrossRef]

99. Stroup, S.S.; Murdie, A. There's no place like home: Explaining international NGO advocacy. Rev. Int. Organ. 2012, 7, 425-448. [CrossRef]

100. Bloodgood, E.A.; Tremblay-Boire, J.; Prakash, A. National Styles of NGO Regulation. Nonprofit Volunt. Sect. Q. 2013, 43, 716-736. [CrossRef]

101. Frangonikolopoulos, C.A. Politics, the Media and NGOs: The Greek Experience. Perspect. Eur. Polit. Soc. 2014, 15, 606-619. [CrossRef]

102. Ceptureanu, S.I.; Ceptureanu, E.G.; Bogdan, V.L.; Radulescu, V. Sustainability perceptions in romanian non-profit organizations: An exploratory study using success factor analysis. Sustainability 2018, 10, 294. [CrossRef]

(C) 2020 by the authors. Licensee MDPI, Basel, Switzerland. This article is an open access article distributed under the terms and conditions of the Creative Commons Attribution (CC BY) license (http://creativecommons.org/licenses/by/4.0/). 